\title{
Role of T Cells in Feline Infectious Peritonitis Virus Infection of Suckling Mice
}

\author{
Takashi TAKENOUCHI, Yasushi AMI, Toshiharu HAYASHI, and Kôsaku FUJIWARA \\ Department of Veterinary Pathology, Faculty of Agriculture, University of Tokyo, \\ 1-1-1 Yayoi, Bunkyo-ku, Tokyo 113, Japan
}

(Received 29 October 1984/Accepted 8 February 1985)

\begin{abstract}
Suckling nude (nu/nu) and heterozygous $(\mathrm{nu} /+)$ mice of age 2 weeks were inoculated intracerebrally with feline infectious peritonitis virus. Mortality of nu/+ mice was significantly lower than that of nu/nu mice. The resistance of nu/+ sucklings was considerably affected by anti-Thy 1.2 serum treatment, and mortality of nu/nu mice was reduced by transfer of $\mathrm{T}$ cells from 2-week-old nu/ + mice. Serum antibody was not detected by immunofluorescence in animals of any group surviving at 10 days postinoculation.-KEY WORDS: FIP, nude mouse, T cell.
\end{abstract}

Jpn. J. Vet. Sci. 47(3): 465-468, 1985

In feline infectious peritonitis (FIP) some authors described the occurrence of severer illness in antibody-positive cats than in negative ones and the enhancement of infection was induced after antibody transfer $[4,5,8$, $9,12-14]$. On the other hand, natural and experimental FIP cases were shown to have lymphopenia and lesions in lymphoid organs [2, 11-14] and thymectomy induced severer lesions [1], suggesting that cell-mediated immunity might play an important role in the host resistance to FIP virus infection. This brief communication deals with the role of $\mathrm{T}$ cells in congenitally athymic nu/nu and nu/ + mice inoculated intracerebrally (i.c.) with a mouse adapted FIP virus, Yayoi strain [3].

A $10 \%(\mathrm{~W} / \mathrm{V})$ homogenate of the infected brain from a suckling mouse at the 65th passage, being prepared in phosphate buffer-

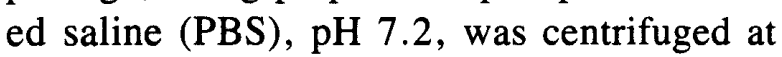
3,000 r.p.m. for $10 \mathrm{~min}$. The supernatant was passed through a $450 \mathrm{~nm}$ Millipore filter (Millipore Corporation, Bedford, MA, U.S.A.), and the filtrates were portioned and stored at $-70^{\circ} \mathrm{C}$. The samples contained approximately $6 \times 10^{6}$ LDso $(25 \mu \mathrm{l}$, i.c., 1 day-old mice) of the virus. As control inocu- lum, a $10 \%(\mathrm{~W} / \mathrm{V})$ brain homogenate of a 4-day-old intact mouse was prepared and injected in the same way.

Five to eight nu/nu or nu/ + animals of the same litters having BALB/c background were nursed by their own mothers and were inoculated i.c. at age 2 weeks. They were examined daily for clinical signs until 10 days postinoculation (p.i.), when surviving animals were sacrificed by ether anesthesia. Mortalities were statistically analyzed between groups by Student-t test. Brains were sampled from some dead and sacrificed animals and transverse sections were made across the diencephalon. For histopathology the anterior half of the brains were fixed in buffered formalin ( $\mathrm{pH} 7.0$ ), embedded in paraffin and stained with hematoxylin and eosin (HE). Cryostat sections were made from the posterior half of the brains and subjected to indirect immunofluorescence for virus antigen [15]. In Experiment I, blood was sampled from the heart and serum antibody titers were evaluated by indirect immunofluorescence on the sections of infected suckling mouse brain using FITC-conjugated anti-mouse IgG sheep serum (Cappel Lab., 
Table 1. Effect of ATS on the mortality of suckling mice inoculated with FIP virus

\begin{tabular}{cccc}
\hline Mouse & ATS $^{\mathrm{a})}$ & FIPV $^{\mathrm{b})}$ & Mortality $(\%)^{\mathrm{c})}$ \\
\hline $\mathrm{nu} / \mathrm{nu}$ & - & + & $7 / 10(10)$ \\
& - & - & $0 / 10$ \\
$\mathrm{nu} /+$ & - & + & $4 / 12(33)$ \\
& + & + & $21 / 30(70)$ \\
& + & - & $0 / 10$ \\
\hline
\end{tabular}

a) 25 and $50 \mu l$ of $\operatorname{ATS}(+)$ or $\operatorname{PBS}(-)$ was given i.p. at 1 and 3 days of age, respectively.

b) FIP virus $\left(6 \times 10^{6} \mathrm{LD} 50\right)(+)$ or control inoculum(-) was given i.c. at 2 weeks of age.

c) At 10 days p.i.

Cochranville, PA, U.S.A.) as the secondary serum.

In Experiment I, two groups of thirty and ten $\mathrm{nu} /+$ mice received intraperitoneally (i.p.) 25 and $50 \mu l$ of anti-thymocyte serum (ATS) at 1 and 3 days of age, respectively. The ATS used was a 1:100 dilution in PBS of a monoclonal mouse IgM antibody to Thy 1.2 (Olac 1976, Bicester, Oxon., U.K.). The other two groups of twenty nu/nu and twelve $\mathrm{nu} /+$ mice were injected i.p. with 25 and 50 $\mu l$ PBS twice at 1 and 3 days of age.

At age 2 weeks all the mice were inoculated i.c. with either FIP virus or the control inoculum. To see effect of ATS peripheral blood samples were collected before virus inoculation and leukocytes were isolated by a Ficoll-Paque (Pharmasia, Uppsala, Sweden) and examined for acid alpha-naphthyl acetate esterase (ANAE)-positive lymphocytes according to Mueller et al. [7]. ANAE-positive cells from ATS-treated $\mathrm{nu} /+$ mice $(44 \pm 8 \%$, $\mathrm{N}=5$ ) were significantly less in number ( $\mathrm{p}<$ $0.001)$ than those from non-treated mice ( 75 $\pm 3 \%, N=4$ ).

On 3 days p.i. or later, all the inoculated suckling mice were depressed or hypersensitive, exhibiting spasm or paresis. Inoculated mice were retarded to grow and some animals died at 3 to 7 days p.i. At 10 days p.i. the mortality of $\mathrm{nu} /+$ mice $(33 \%)$ was significantly lower $(\mathrm{p}<0.05)$ than that of $\mathrm{nu} / \mathrm{nu}$

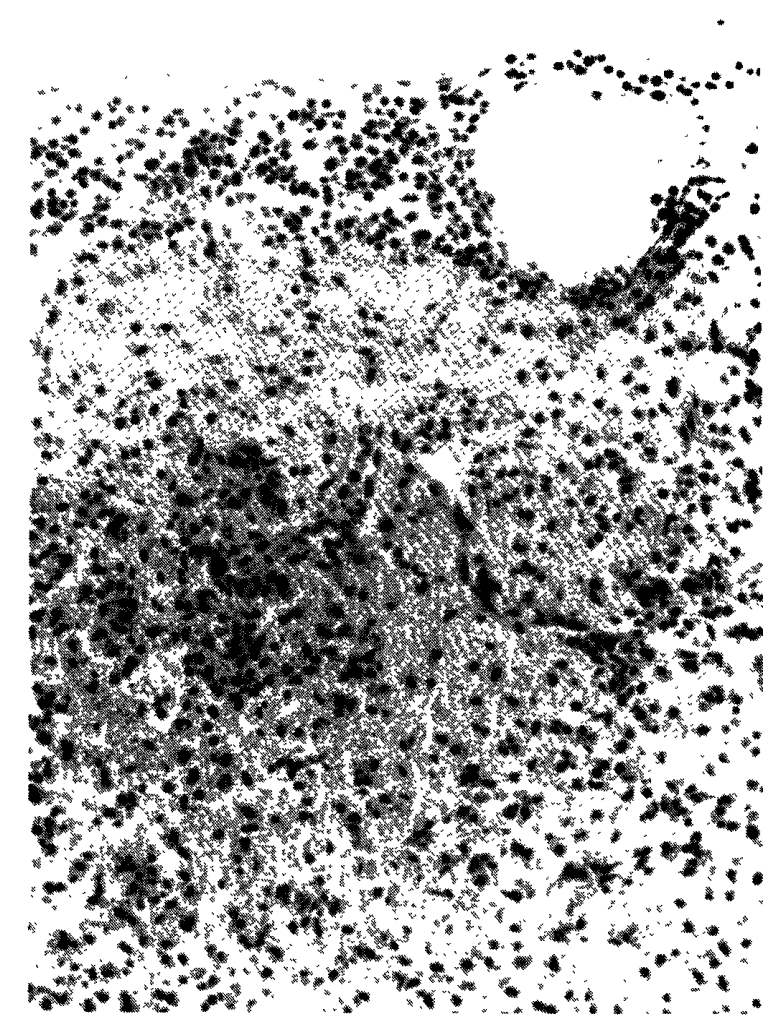

Fig. 1. Submeningeal infiltration with focal necrosis in the cerebral cortex in a $\mathrm{nu} /+$ mouse killed at 10 days p.i. HE. $\times 100$.

mice $(70 \%)$ (Table 1). In ATS treated nu/+ mice, however, mortality was $70 \%$, being higher $(\mathrm{p}<0.05)$ than in $\mathrm{nu} /+$ mice without ATS treatment. After receiving control inoculum containing no virus, no animal died in both $\mathrm{nu} / \mathrm{nu}$ and $\mathrm{nu} /+$ groups.

Microscopically necrotic lesions were extensive with weak inflammatory reactions in $\mathrm{nu} / \mathrm{nu}$ mice which died between 4 to 6 days p.i. In most nu/nu survivors, however, necrosis was less extensive with some inflammatory reactions. In surviving $\mathrm{nu} /+$ mice with or without ATS treatment, necrotic foci were much less in number and extensiveness with intense inflammatory reactions as compared to $\mathrm{nu} / \mathrm{nu}$ mice.

In virus-infected mice of any groups the brain lesions were characterized by bilateral necrosis of the cerebral cortex and hippocampus. The cerebral nuclei and diencephalon were sometimes involved. Lymphocytes, 


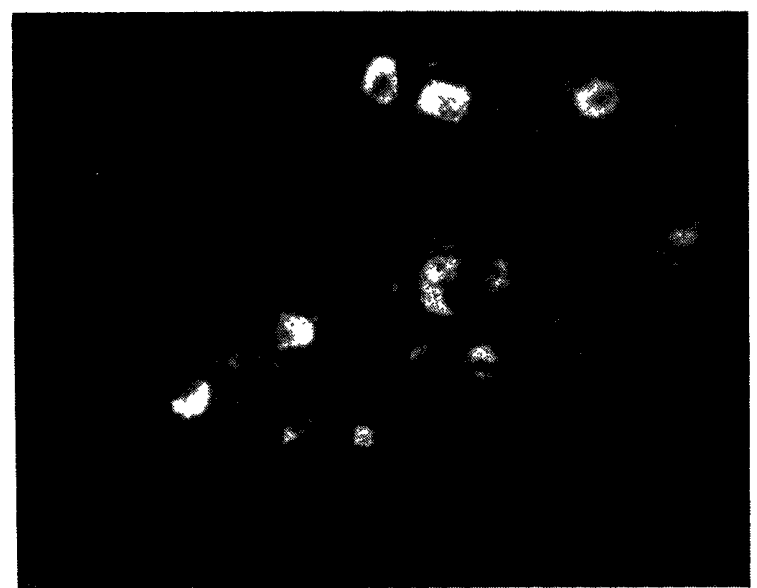

Fig. 2. Virus-specific fluorescence within cortical neurons and glias of a nu/ + mouse killed at 10 days p.i. (the same animal as shown in Fig. 1). Indirect immunofluorescence. $\times 200$.

macrophages, plasma cells and a few neutrophils were present at the submeningeal areas, and some lymphocytes appeared also at perivascular areas (Fig. 1). In animals which had received control inoculum, no significant change was observed.

In all inoculated and dead animals as well as some of survivours, virus antigen was detected mainly in the cytoplasm of neurons and glias. The specific fluorescence positive cells were first localized to the cerebral cortex and hippocampus, being most numerous in $\mathrm{nu} / \mathrm{nu}$ mice which died at 4 to 6 days p.i. (Fig. 2). No specific fluorescence was detected in the submeningeal and perivascular areas nor within blood vessels. Attempt at detecting IgG deposition was made revealing only faint fluorescence in the parenchyma of the cerebrum. No serum antibody was detected in survivors examined.

In Experiment II effect of $\mathrm{T}$ cell transfer from $\mathrm{nu} /+$ mice on infection of nu/nu mice was observed (Table 2). After hemolysis in $\mathrm{NH}_{4} \mathrm{Cl}$-Tris buffer, splenocytes from 2-weekold $\mathrm{nu} /+$ mice were suspended in RPMI 1640 (Gibco Lab., Grand Island, NY, U.S.A.) supplemented with $10 \%$ fetal calf serum heated at $56^{\circ} \mathrm{C}$ for $30 \mathrm{~min}, 100 \mu \mathrm{g} / \mathrm{ml}$ kanamycin and $10 \mathrm{mM} \mathrm{N}$-2-hydroxyethylpiperazine-N'-
Table 2. Effect of splenic T cell transfer from $\mathrm{nu} /+$ mice on FIP virus infection in $\mathrm{nu} / \mathrm{nu}$ suckling mice

\begin{tabular}{lcc}
\hline \multicolumn{1}{c}{ Mouse $^{\mathrm{a})}$} & $\begin{array}{c}\text { T cellb) } \\
\text { transfer }\end{array}$ & Mortality $(\%)$ \\
\hline $\mathrm{nu} /+$ & - & $4 / 10(40)$ \\
$\mathrm{nu} / \mathrm{nu}$ & - & $8 / 10(80)$ \\
& + & $12 / 20(60)$ \\
\hline
\end{tabular}

a) 2-week-old of age.

b) $3 \times 10^{7} \mathrm{~T}$ cells $(+)$ or $0.2 \mathrm{ml}$ PBS (-) was injected i.v. within $2 \mathrm{hr}$ p.i. $\left(6 \times 10^{6} \mathrm{LD}_{s 0}\right.$, i.c.).

2-ethanesulfonic acid (Dotite HEPES, Wako Chemical, Tokyo). A $T$ cell rich fraction was obtained by filtration through a nylon wool (Wako Chemical) column according to Julius et al. [6], and the suspension $\left(3 \times 10^{7}\right.$ viable cells in $0.2 \mathrm{~m} l \mathrm{PBS}, \mathrm{pH} 7.2$ ) was transferred intravenously (i.v.) to twenty 2-week-old nu/ nu mice within $2 \mathrm{hr}$ p.i. The ANAE-positive cells in the suspension were $89 \pm 2 \%(\mathrm{~N}=4)$. As controls another group of ten mice was given i.v. $0.2 \mathrm{ml}$ PBS.

The mortality of $\mathrm{nu} /+$ mice $(40 \%)$ was significantly lower $(p<0.05)$ than that of $\mathrm{nu} / \mathrm{nu}$ mice $(80 \%)$ as observed in Experiment I (Table 2). Pathological and immunofluorescent findings were essentially similar to those in Experiment I. In nu/nu mice having received the transfer of $\mathrm{T}$ cells from $\mathrm{nu} /+$ mice showed a mortality of $60 \%$ and similar findings to those of $\mathrm{nu} /+$ mice.

The present studies revealed that $\mathrm{nu} / \mathrm{nu}$ mice were more susceptible than $\mathrm{nu} /+$ mice by i.c. inoculation of FIP virus and that nu/nu mice were shown to be resistant after transfer of $\mathrm{T}$ cells from $\mathrm{nu} /+$ mice. On the other hand, nu/ + mice became more susceptible after ATS treatment. By indirect immunofluorescence the circulating antibody was not detectable in survivors of any groups at 10 days p.i. As a correlation was evidenced between antibody titers by indirect immunofluorescence and those by neutralization test [3], the resistance of suckling mice to FIP 
virus infection would be mostly T-cell mediated.

The extensiveness and distribution of necrotic lesions reflected the presence of virus antigen. Using the 16th passage level of the Yayoi strain of FIP virus, the onset of clinical signs and death occurred at 4 days p.i. in 1-day-old mice given an LDso for 1-day-old mice $\left(3 \times 10^{3} / 25 \mu l\right.$, i.c. $)$ [3]. In this study using the 65 th passage level of the same virus, however, mice showed an early onset even in 2-week-old mice given an LDso $\left(6 \times 10^{6} / 25 \mu\right.$ l, i.c. $)$. Thus, the virulence of the virus strain for mice seems to have augmented after many passages in mice. The susceptibility of mice to FIP virus was agedependent, and even in suckling mice, intranasal, intramuscular or i.p. route of inoculation never resulted in virus multiplication in any organs (unpublished observation).

Some authors [9, 13] proposed Arthus phenomenon for inducing the effusive type of FIP, based on the presence of FIP virus antigen, IgG and $\mathrm{C} 3$ within macrophages which were believed to be an initial target of the virus. In the present cases of suckling mice, however, there were little vascular damage and neutrophil infiltration, and no virus antigen was detected in the submeningeal or perivascular areas nor within blood vessels. Although antibody dependent cellmediated cytotoxicity was described to play a major role in tissue damage in acute mouse hepatitis virus infection, another member of
Coronaviridae [10], the involvement of the same mechanism might not be probable in the present cases because of the absence of virus antigen and IgG in neurons and glias and of circulating antibody.

\section{REFERENCES}

1. Hayashi, T., Sasaki, N., Ami, Y., and Fujiwara, K. 1983. Jpn. J. Vet. Sci. 45: 759-766.

2. Hayashi, T., Utsumi, F., Takahashi, R., and Fujiwara, K. 1980. Jpn. J. Vet. Sci. 42: 197-210.

3. Hayashi, T., Yanai, T., Tsurudome, M., Nakayama, H., Watabe, Y., and Fujiwara, K. 1981. Jpn. J. Vet. Sci. 43: 669-676.

4. Hayashi, T., Watabe, Y., Takenouchi, T., and Fujiwara, K. 1983. Jpn. J. Vet. Sci. 45: 487-494.

5. Jacobse-Geels, H. E. L., Daha, M. R., and Horzinek, M. C. 1982. Am. J. Vet. Res. 43: 666-670.

6. Julius, M. H., Simpson, E., and Herzenberg, L. A. 1973. Eur. J. Immunol. 3: 645-649.

7. Mueller, J., Brun del Re, G., Buerki, H., Keller, H. U., Hess, M. W., and Cottier, H. 1975. Eur. J. Immunol. 5: 270-274.

8. Pedersen, N. C., and Black, J. W. 1983. Am. J. Vet. Res. 44: 229-234.

9. Pedersen, N. C., and Boyle, J. F. 1980. Am. J. Vet Res. 41: 868-876.

10. Taoka, Y., and Endo, Y. 1980. J. UOEH. 2: $75-83$.

11. Ward, J. M., Gribble, D. H., and Dungworth, D. L. 1974. Am. J. Vet. Res. 35: 1271-1275.

12. Weiss, R. C., Dodds, W. J., and Scott, F. W. 1980. Am. J. Vet. Res. 41: 663-671.

13. Weiss, R. C., and Scott, F. W. 1981. Comp. Immun. Microbiol. Infect. Dis. 4: 175-189.

14. Weiss, R. C., and Scott, F. W. 1981. Am. J. Vet. Res. 42: 2036-2048.

15. Yanagisawa, T., Hayashi, T., and Fujiwara, K. 1983. Jpn. J. Vet. Sci. 45: 117-122.

\section{要 約}

乳のみマウスのネコ伝染性腹膜炎 (FIP) ウイルス感染に抢ける $\mathrm{T}$ 細胞の役割（短報）：竹之内俊・網 康至・ 林 俊春・藤原公策（東京大学農学部家音病理学教室）—FIP ウイルスを14日齢のヌードマウス $(\mathrm{nu} / \mathrm{nu})$ およ びへテロマウス $(\mathrm{nu} /+$ ) に脳内接種すると, nu/nu は nu/+ にくらべて高い死亡率を示した。 $\mathrm{nu} /+$ マウス 脾 $\mathrm{T}$ 細胞を移入することにより, nu/nu の死亡率は低下し，抗胸腺細胞抗血清処置 $\mathrm{nu} /+$ の死亡率は無処置の 場合より高かった。血清抗体は間接蛍光抗体法により全例に执いて陰性であった。 